\title{
Analysis of factors influencing energy efficiency in a Smart Metering Pilot
}

Uldis Bariss,

Ilze Laicane,

\section{Dagnija Blumberga}

Institute of Energy Systems

and Environment,

Riga Technical University,

1 Kronvalda Blvd.,

Riga, LV-1010, Latvia

E-mail: uldis.bariss@latvenergo.lv
This paper analyzes the results of providing smart meters and appropriate feedback on electricity consumption in a pilot study involving around 1000 households in Latvia. The findings from our study have shown that smart meter roll-out and provision of appropriate feedback information can provide significant energy savings for household customers. In comparison with the control group the average consumption of the target group fell by $19 \%$ year by year. Additionally, there was identified in the consumption group 0-399 kWh per month that feedback enabled by smart meters motivated to consume less electricity those customers who recognize options how to change their energy consumption behavior. It was also identified that customer willingness to receive additional information does not necessarily correspond with later actions to reduce consumption. This could be related to actual or desired behavior that together with feedback induced motivation results into energy saving actions.

Key words: electricity consumption, smart meters, households, feedback pilot

\section{INTRODUCTION}

Energy sector is an important factor influencing the quality of live and economic prosperity of a nation. Energy consumption is not only the important indicator of the socioeconomic status of the population. It is also the main factor in its impact on the environment. The European Union (EU) has developed a climate and energy package which aims to ensure that the EU meets its ambitious climate and energy targets for 2020. These are known as the "20-20-20" targets, 
which comprise three main objectives that have to be reached by 2020 . Those are $20 \%$ reduction in EU greenhouse gas emissions from 1990 levels, raising the share of EU energy consumption produced from renewable resources to $20 \%$ and a $20 \%$ improvement in the EU's energy efficiency. The electricity directive promotes a target for the implementation of intelligent metering systems by 2020 , where costs and benefits of the roll-out of smart meters are assessed positively. Additionally, the energy efficiency directive has set the binding target to save primary energy resources annually by $1.5 \%$. These initiatives have highlighted scientific and policy debates about factors influencing success of smart meter roll-outs and energy efficiency improvements.

\section{Feedback programs}

The role of feedback is to make energy consumption visible, thus, creating the knowledge of residential consumers about how much energy is consumed and how much they actually pay for energy. There are a number of pilot projects and research work exploring potential energy savings by providing better information and feedback on consumption to households. The feedback about usage enables consumers to reduce their electricity demand through conservation activities that is through changing behavior or making ener- gy-efficiency investments in lighting or household appliances.

Feedback effect was demonstrated in a large scale natural experiment that has been carried out in Northern Ireland after the installation of smart meters in 2002. It can be safely assumed that those who have the possibility to monitor their consumption through the installed feedback displays will do so as electricity is prepaid in the region. Quite pronounced decrease in electricity consumption was observed since the installation of the smart metering system (Fig. 1).

There is a number of smart metering pilots carried out over last decades in order to study feedback effects and behavioral factors influencing outcomes. The review of pilots carried out by Darby (2006) suggests that the norm for savings from direct feedback, that is an immediate feedback from the meter or an associated display monitor, is in a range from $5-15 \%$. There is also an indication that high energy consumers may respond more to the direct feedback than low users [2]. Indirect feedback is processed in some way before reaching the energy user that is normally either via billing or web service solutions. Savings in this case have ranged from $0-10 \%$, but they vary according to the quality of information provided. Historic feedback that

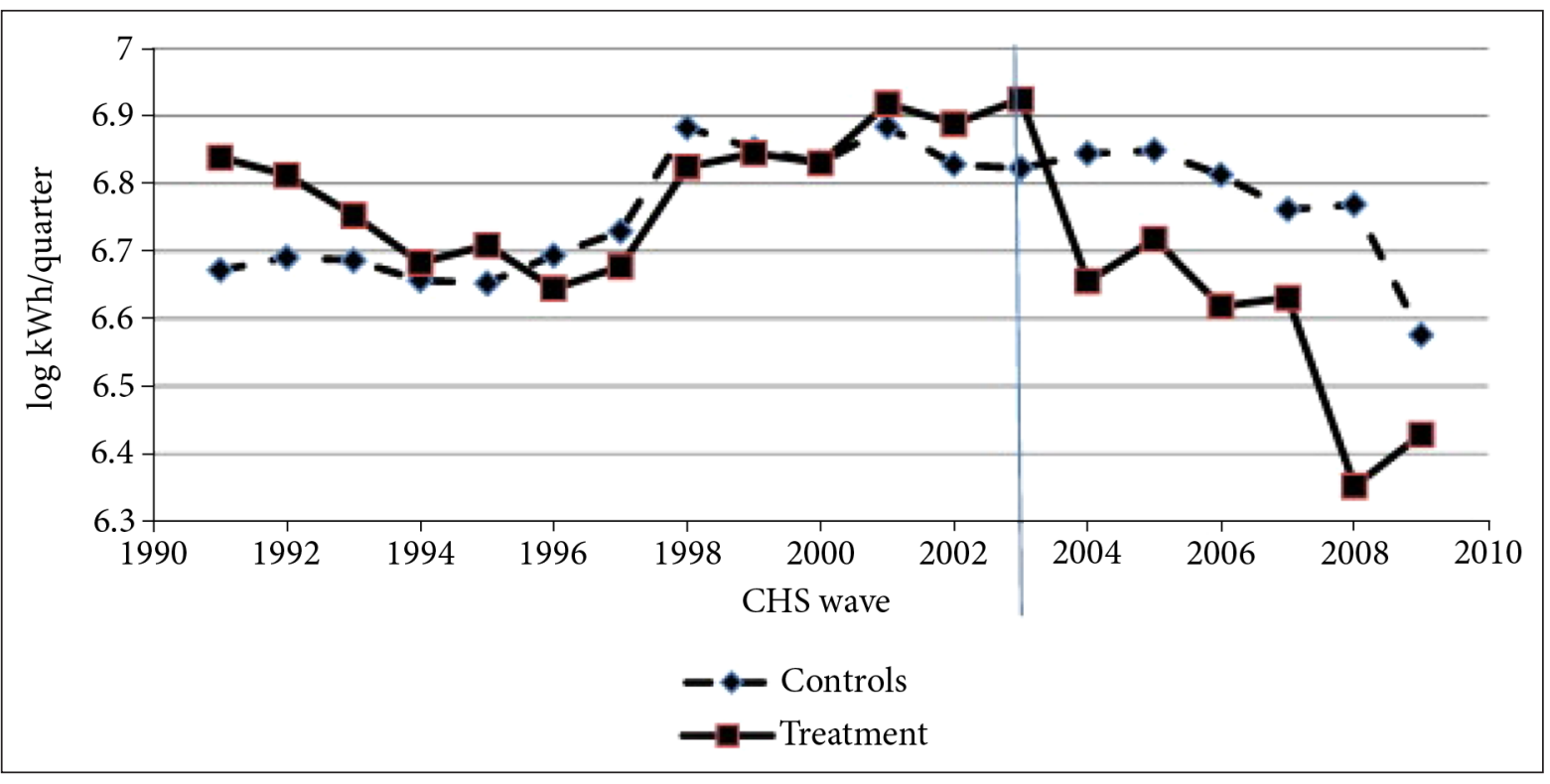

Fig. 1. Electricity consumption: average for prepayment (treatment) and control households (not adjusted for household characteristics) by year [1] 
provides comparison with previous recorded periods of consumption is reported to be more effective than comparing with other similar households, or with a target figure [2]. Feedback study carried out by Ehrhardt-Martinez et al. (2010) of 57 initiatives in general supports these findings; however, it shows average household energy savings of roughly 4 to $12 \%$ that is a slightly tighter range. For direct feedback types this study reports average household electricity savings of $5.5 \%$ for enhanced billing, $6.8 \%$ for estimated feedback and $11.0 \%$ for daily / weekly feedback. For direct feedback types, EhrhardtMartinez et al. (2010) state average savings of $8.6 \%$ for aggregated real-time information on electricity usage, and $13.7 \%$ if such feedback is provided at the level of individual appliances [3]. Vaasa ETT's report involved collecting and comparing about 100 pilots. In general, it has shown lower level feedback effect. In comparison with other feedback channels, in-house displays resulted in the highest energy savings $8.7 \%$. The remaining channels for feedback produced almost equal consumption reduction levels. These average pilot results for detailed invoices are 6\% but for webpage feedback 5.1\% [4].

\section{Factors influencing feedback reaction}

The existing studies suggest that most of the energy savings achieved through feedback programs result from changes in behaviors but not investments. At the same time people who invest tend to save the most energy [3]. Therefore, it is important to identify factors influencing customer behavior and consequently energy savings. There is a number of studies that analyzed various factors influencing customer reaction to feedback enabled by smart meters.

So, economic and environmental effects of the implementation of water and electricity smart metering systems in Brazil were studied by Lima et al. (2012) [5]. It concludes that the success of investment depends on the commitment of customers and a change in the perception of the inherent value of the electricity. At the same time making excessive information available for consumers is ineffective.

Anda M., Temmen J. (2013) explain how a reduction in peak demand and overall energy consumption can be achieved by extensive change to advanced metering systems or smart meters combined with community-based social marketing in urban environment. In addition to providing of in-house displays, authors attempted to shift network consumption peaks by coaching of the participants, advising them to, for example, use a washing machine only when it is full and after $11 \mathrm{PM}$. Their main aim is to include all energy market participants (producers, suppliers, consumers) in order to achieve the optimal operation of the smart grid and full usage of its beneficial potential for all participants [6].

The effect of smart energy meters on household energy consumption for heating was addressed by Chris Ivanov. The EnergyWise Smart Meter Pilot project involved 1000 participants from the suburban city of Andover in USA. Meters that captured energy use every 15 minutes were installed for all participants, 125 treatment homes were equipped with programmable thermostats and in-home Trilliant Networks display devices. Display devices showed not only current energy consumption and its cost, but also day's conditions and forecast of when there will be peak consumption. There were also "red alert" days when the company turned up air conditioner setting by $3{ }^{\circ} \mathrm{F}$ without residents prior knowledge as an experiment. Daily changes in consumption were assessed. Study indicates that peak energy reduction is around $16 \%$ with enabling technologies like smart thermostats. The study showed that direct feedback coupled with appropriate customer information could achieve very significant savings. However, this work concentrates only on peak demand and does not offer any data about the changes of energy consumption in the long term [7].

A behavioral reaction of customers to direct feedback was analyzed by Oltra H. et al. [8] in a pilot where in-house displays were used. Results indicate that saving might be moderated by the level of user's engagement with the display, preceded by user's motivation to save energy, prior attitudes and, importantly, the level of involvement generated by the intervention. The study proved that collective involvement and education can significantly contribute to change of behavior and consequently feedback results [8].

Additionally, it is suggested that energy savings are likely to vary by income level such that 
higher income households are more likely to purchase new energy efficient appliances and devices while lower income households are more likely to engage in energy saving behavior or change their energy usage habits and routines [3]. However, there are reports that have not found any positive correlation to income but reports dependency on consumption level. For example, the field trial in Austria did not find this correlation. However, it showed that for households in the 30th to the 70th percentile of electricity consumption there was a statistically significant feedback effect on electricity consumption but for percentiles below or above this range feedback appeared to have no effect. The trial reports savings of around $4.5 \%$ for the average household [9].

There is a discussion whether a program will continue to have an impact on consumer behavior also after it ends. In order to better understand this Vaasa ETT's report pilots were compared according to their length. The results showed that, with the exception of the time-of-use pilot samples, longer pilots have similar or higher results than shorter ones [4]. This effect is shown also in an analysis of residential electricity consumption in Northern Ireland. The analysis of few years around the introduction of the advanced metering system shows that the feedback effect is reported at $10-13 \%$ reduction in electricity usage. However, taking into account the entire set of data for the period of 1990 to 2009, the paper reports stronger effect up to about 17 to $18 \%$ of electricity usage savings [1].

Smart meters are expected to play a major role in future development of energy supply systems. Therefore, it is important to understand how they will impact low level consumers. The study by Darby S. [10] concludes that smart meters have the potential to alleviate fuel poverty, primarily through provision of better feedback to assist with energy management, and through simplifying and encouraging prepayment and supplier switching [10]. Based on these findings there could be important to reassess factors influencing feedback also of lower end consumption customers because usually it is assumed that there is a little benefit for smart meter rollout in this category.

The wide range of effects of reported feedback results could be explained by different evaluation methodologies ex-ante versus ex-post evaluation, definition of target and control groups, by different duration of pilots that involve long-run versus short run-effects. Additionally, there are a number of factors, such as the distribution of household consumption, weather conditions, local energy usage habits and appliances' stock, feedback content in its relevance within a particular market. Therefore, it is important to analyze feedback effects in the local context that was the aim of this study.

\section{METHODOLOGY}

\section{Pilot group}

The design of this study was based on a quantitative design with two research strategies. First, there is set up a target group of households with smart meters that are compared to a control group of households without smart meters in order to assess the feedback effect in the local market conditions. Secondly, there is carried out a survey in order to identify possible factors that are influencing the feedback effects. The tasks of the research are to assess the feedback effect in different household groups based on their consumption and to analyze potential factors identified in the survey that do have influence on the feedback effect level.

The participating households for the case study trial were selected in three steps. In the first step, an initial list of 20000 potential participants was selected identifying respondents in the set of consumption groups by the energy utility from their billing system. For this study, a questionnaire was designed to collect data for various potential factors that could correlate to energy consumption changes due to the provided feedback information. That includes a number of appliances used in a household, customer's attitude towards potential reduction of usage of particular appliances, customer attitude towards information regarding energy efficiency, demographic factors of a household including income level, etc.

Then computer-assisted telephone interviews were conducted with households randomly assigned to a target group and a control group selecting in total 1000 households. The interviews comprised questions about household appliances, 
energy usage and socio-demographic characteristics. The target group participants were asked for consent to participate in the case study and install a smart meter. Control group households received information about the study on energy consumption; however, they were not informed about a smart meter pilot. In the third step, there were smart meters installed for the target group households and binding participation and acceptance of a privacy agreement signed. The case study was started in April 2013 and data are currently available up to November 2013.

The participants of the target group are receiving monthly bills based on the actual consumption data. Additionally, there is provided on-line access to the consumption data based on a $5 \mathrm{~min}$ ute integration period. This type of feedback was chosen in order to have the feedback conditions that would be close to circumstances of the main roll-out. For the control group no smart electricity meters were installed and this group was only observed based on monthly self-reading. This is a traditional billing method for electricity in Latvia, whereby customers communicate the readings from their meter to the energy supplier but an electricity distribution company is carrying out annual control checks.

The results in this paper are part of an ongoing study project and represent one of the attempts to explore feedback effect on consumption behavior and factors influencing households' attitudes.

\section{Data}

In order to identify the effect from feedback on actual consumption for the target group, year by year consumption changes of the customer with smart meters were compared with energy consumption changes in the control group. The data from the control group is used to exclude the effect from factors such as changes in weather conditions, seasonality factors, etc. Electricity prices for households have not varied during our study period and there have not been significant price changes two years before the study. Therefore, it can be assumed that the identified relative reduction can be attributed to the effect by installation of smart meters and provided feedback for actual consumption.

The households within the target and control groups were sorted based on the monthly amount of electricity consumed in the 6 following subgroups: 0-249, 250-399, 400-699, 700-1499, $1500-1899$ and more than $1900 \mathrm{kWh}$. This subdivision is chosen to have statistically representative groups in both subsets - the target group and the control group.

Relative changes in electricity consumption for a subgroup of the target and control groups, $E_{\text {subgroup }}(\%)$, are accordingly calculated as

$$
\begin{aligned}
& E_{\text {subgroup }(\%)}=\left(\sum_{1}^{n} E 2013_{i}-\sum_{1}^{n} E 2012_{i}\right) \div \\
& \div \sum_{1}^{n} E 2012_{i} \times 100 \%,
\end{aligned}
$$

where $E 2013_{i}$ and $E 2012_{i}$ represent electricity consumption of a respondent in the period from April till November correspondingly in the years 2013 and 2012.

Taking into account that during the case study there could be respondents who might have moved out of premises or for other reasons would have extreme consumption changes so distorting results for the whole subgroup, significant outlying data identification was carried out. In order to identify such data the outlier labeling rule was used [11]. This test was performed for each consumption subgroup separately setting upper and lower limits for minimal and maximal values as follows:

$$
\begin{aligned}
& \text { Upper limit }=Q_{3}+\left(2.2 \times\left(Q_{3}-Q_{1}\right)\right) \\
& \text { Lower limit }=Q_{1}+\left(2.2 \times\left(Q_{3}-Q_{1}\right)\right)
\end{aligned}
$$

where $Q_{1}$ is a lower quartile and $Q_{3}$ is an upper quartile of the data in a subgroup but 2.2 is a multiplication factor.

In total, 41 data from 1054 data were trimmed that corresponds to $4 \%$. Most variability was presented in the control group where data from 30 respondents were outside limits calculated based on Eq. (1) and Eq. (2). The target group contained only $2 \%$ of data that were outside those limits that could be explained by variability of consumption data that are based on monthly self-reading.

The independent-samples t-test was used to compare the means of relative consumption changes between the corresponding subgroups of the analyzed factors influencing relative con- 
sumption changes as they are two unrelated groups on the same continuous, dependent variable.

\section{RESULTS}

The data from the pilot study show that roll-out of smart meters can significantly improve energy efficiency simply by providing feed-back information about actual consumption and delivering a monthly bill based on actual data. However, energy efficiency gains were significantly different among different consumption groups as shown in Fig. 2.

In comparison with the control group the average consumption of the target group fell by $19 \%$ year by year. At the same time there was $2 \%$ reduction for consumers with average monthly consumption between 250 and $399 \mathrm{kWh}$ per month but slightly above $20 \%$ consumption decrease in the range above $1500 \mathrm{kWh} /$ month. These electricity savings in percentage terms are significantly over the range that is reported by other pilot studies that describe savings in the range from 5 to $15 \%$ depending on the feed-back type $[3,4]$.

A possible explanation may be that in this study customers with a relatively high consumption level were selected well above an average consumption for the population that is close to $200 \mathrm{kWh}$ per month. At the same time it could be that income level for high level consumers in Latvia is considerably lower than for other EU countries that might explain why in this study there was not observed reduction of feedback effect at higher consumption what was reported by Schleich et al. [9] in the trail carried out in Austria. Also unexpected results were demonstrated in the consumption range $250-399 \mathrm{kWh}$ per month, where almost no feedback effect was identified. As this is a consumption level above the average level in Latvia, it could be assumed that there are on average represented middle class households that should be more inclined to adopt efficiency measures, including investments in more efficient lighting and home appliances. Additionally, an unexpected result is the $11 \%$ reduction in the monthly consumption of households within the range 0 to $249 \mathrm{kWh}$. Assuming that this consumption range would partly correspond to low income households many of whom cannot afford higher efficiency devices, these results would need additional analysis.

Feedback pilots tend to produce considerably diverse results. There are identified various factors that could be generally associated with two broad categories - the feedback type and the customer. Factors related to the user that influence the effect of feedback on energy saving behavior may include users' values, beliefs and norms, user's routines, personal capabilities, level of household energy consumption, household background and contextual characteristics [12]. An important factor that could affect customer behavior

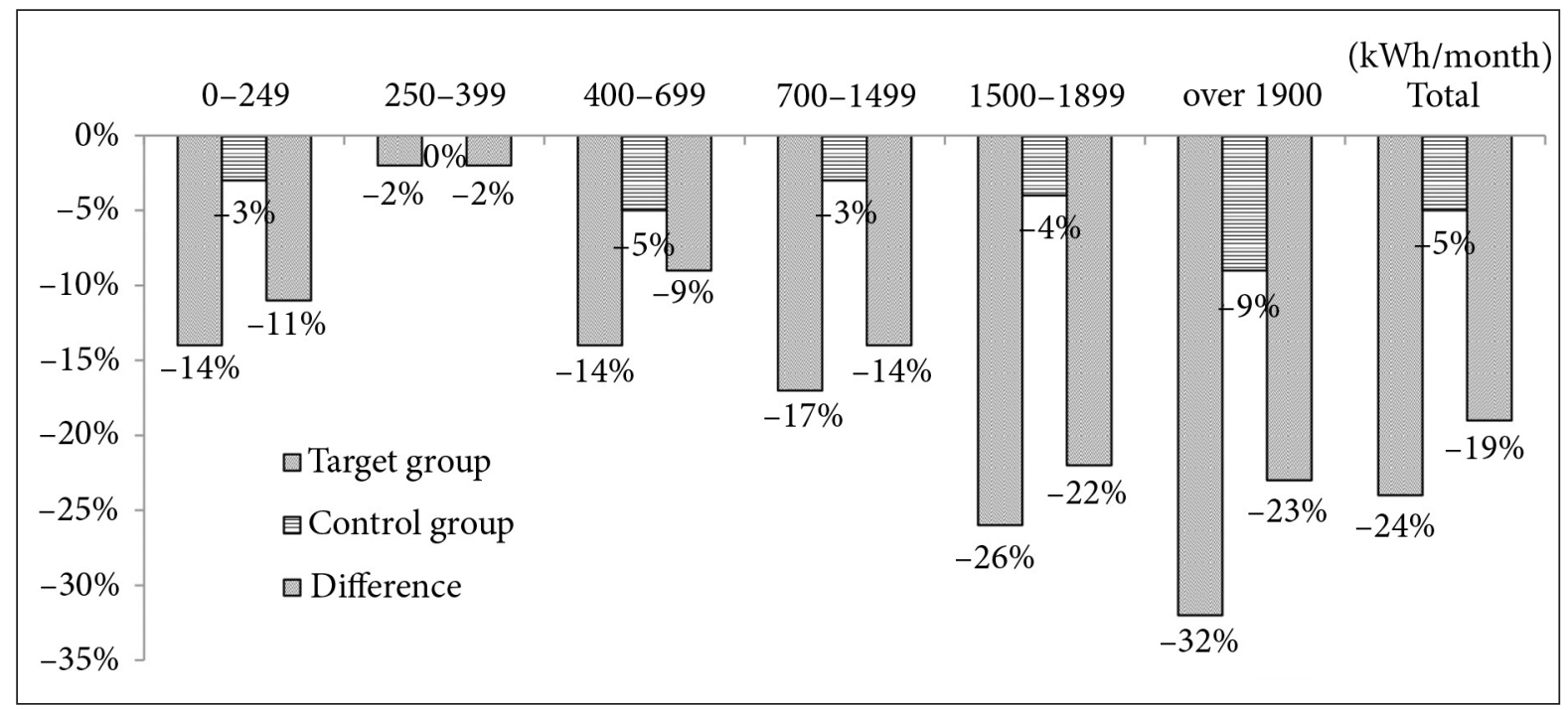

Fig. 2. Relative electricity consumption changes for the target and control groups 
is its belief on how much they could change their consumption pattern and reduce electricity usage if they would have such motivation. Therefore, in the survey respondents were asked to list appliances they have in the household and categorize them into three types as follows:

1. Appliances that are essential in their household and cannot be used less;

2. Appliances that could be used less;

3. Appliances that could be almost fully stopped to use.

The results are given in Appendix A. In order to compare the answers, standard nominal power was assigned to each appliance and relative power distribution was calculated for each category based on the survey results. Users have categorized $79.8 \%$ in terms of the nominal power of appliances as essential and that cannot be used less. $10.7 \%$ gave an answer that it could be used less, where most quoted were an electric oven, a dishwasher and an iron. 9.5\% were assigned to the category where usage could be almost fully stopped and the most quoted were portable electric heaters and conditioning systems.

In order to assess how these attitudes might affect consumption behavior, a correlation anal- ysis was carried out using all respondents from the target group. There were no correlation identified that would meet significance test or p-value to be less than 0.05. Also no correlation for the whole group was found for such characteristics as income level, prior knowledge of energy efficiency measures, interest to be engaged in energy efficiency activities. However, there was identified that there is a difference in a change of consumption between respondents that were identified to have more possibilities to save energy in comparison to those who have quoted less or almost no possibilities to save. As shown in Table 1 , there is a statistically significant difference between the means of consumption reduction in the consumption range $0-399 \mathrm{kWh}$ per month.

Those respondents, who before installation of a smart meter have answered that they could have potential to use energy less, also during the pilot study have used $10.8 \%$ less but at the same time other respondents in this group even have increased their consumption on an average by $1.4 \%$. However, this factor has not been identified for higher consumption groups. Also it was not present in the control group that could lead to the

Table 1. Electricity consumption changes between the corresponding periods of 2013 and 2012 subdivided in groups based on respondents' attitude towards their ability to change usage of their household's appliances

\begin{tabular}{|c|c|c|c|c|c|c|c|}
\hline \multirow{4}{*}{$\begin{array}{c}\text { Subgroups } \\
\text { monthly } \\
\text { consumption }\end{array}$} & \multirow{4}{*}{$\begin{array}{c}\text { Number } \\
\text { of } \\
\text { participants }\end{array}$} & \multirow{4}{*}{$\begin{array}{l}\text { Mean of } \\
\text { consump- } \\
\text { tion } \\
\text { reduction }^{\mathrm{a}}\end{array}$} & \multirow{4}{*}{$\begin{array}{l}\text { Mean of } \\
\text { consump- } \\
\text { tion } \\
\text { reduction }\end{array}$} & \multicolumn{4}{|c|}{$\begin{array}{l}t \text {-Test for equality of means } \\
\text { for consumption reduction }\end{array}$} \\
\hline & & & & \multicolumn{2}{|c|}{$\begin{array}{l}\text { Equal variances } \\
\text { assumed }\end{array}$} & \multicolumn{2}{|c|}{$\begin{array}{l}\text { Equal variances } \\
\text { not assumed }\end{array}$} \\
\hline & & & & Significance & Std Error & Significance & Std Error \\
\hline & & & & 2-tailed & Difference & 2-tailed & Difference \\
\hline kWh & & $\%$ & $\%$ & & $\%$ & & $\%$ \\
\hline \multicolumn{8}{|l|}{$\begin{array}{l}\text { Target } \\
\text { group }\end{array}$} \\
\hline $0-399$ & 133 & 1.4 & -10.8 & 0.043 & 6.0 & 0.044 & 6.0 \\
\hline $400-1499$ & 172 & -13.7 & -10.5 & 0.459 & 3.2 & 0.459 & 3.2 \\
\hline Above 1500 & 133 & -21.1 & -24.4 & 0.530 & 5.2 & 0.530 & 5.2 \\
\hline \multicolumn{8}{|l|}{$\begin{array}{l}\text { Control } \\
\text { group }\end{array}$} \\
\hline $0-399$ & 160 & 8.1 & 5.4 & 0.695 & 7.0 & 0.699 & 7.1 \\
\hline $400-1499$ & 230 & -0.3 & 7.3 & 0.219 & 6.2 & 0.221 & 6.2 \\
\hline Above 1500 & 108 & -4.4 & 1.1 & 0.456 & 7.4 & 0.456 & 7.4 \\
\hline
\end{tabular}

Consumption reduction was analyzed based on the distribution of respondent's assessment on a number of appliances that could be used more rarely, expressing in a relative proportion in terms of the nominal power of all appliances in a household.

${ }^{a}$ Respondents under the median, i. e. those who stated that they have less appliances that can be used less.

${ }^{b}$ Respondents above the median, i. e. those who stated that they have more appliances that could be used more rarely. 
Table 2. Electricity consumption changes between the corresponding periods of 2013 and 2012 subdivided in groups based on respondents' attitude towards their willingness to receive information comparing their consumption with other relevant households

\begin{tabular}{|c|c|c|c|c|c|c|c|c|}
\hline \multirow{3}{*}{$\begin{array}{c}\text { Subgroups } \\
\text { monthly } \\
\end{array}$} & \multirow{2}{*}{\multicolumn{2}{|c|}{$\begin{array}{c}\begin{array}{c}\text { Number of } \\
\text { participants }\end{array} \\
\text { answering on }\end{array}$}} & \multirow{3}{*}{$\begin{array}{l}\text { Mean of } \\
\text { consump- } \\
\text { tion } \\
\text { reduction }\end{array}$} & \multirow{3}{*}{$\begin{array}{l}\text { Mean of } \\
\text { consump- } \\
\text { tion } \\
\text { reduction }\end{array}$} & \multicolumn{4}{|c|}{$\begin{array}{l}t \text {-Test for equality of means } \\
\text { for consumption reduction }\end{array}$} \\
\hline & & & & & \multicolumn{2}{|c|}{$\begin{array}{l}\text { Equal variances } \\
\text { assumed }\end{array}$} & \multicolumn{2}{|c|}{$\begin{array}{l}\text { Equal variances } \\
\text { not assumed }\end{array}$} \\
\hline & \multicolumn{2}{|c|}{ willingness to receive } & & & Significance & Std Error & Significance & Std Error \\
\hline consumption & \multicolumn{2}{|c|}{$\begin{array}{l}\text { comparison } \\
\text { information }\end{array}$} & $\begin{array}{l}\text { Group } \\
\text { Yes }\end{array}$ & $\begin{array}{c}\text { Group } \\
\text { No }\end{array}$ & 2-tailed & Difference & 2-tailed & Difference \\
\hline kWh & Yes & No & $\%$ & $\%$ & & $\%$ & & $\%$ \\
\hline \multicolumn{9}{|l|}{$\begin{array}{l}\text { Target } \\
\text { group }\end{array}$} \\
\hline $0-399$ & 51 & 57 & -7.4 & -5.1 & 0.734 & 6.8 & 0.728 & 6.6 \\
\hline Above 400 & 132 & 179 & -11.8 & -20.8 & 0.009 & 3.4 & 0.010 & 3.5 \\
\hline \multicolumn{9}{|l|}{$\begin{array}{l}\text { Control } \\
\text { group }\end{array}$} \\
\hline $0-399$ & 59 & 99 & 18.0 & 0.2 & 0.013 & 7.2 & 0.031 & 8.2 \\
\hline Above 400 & 118 & 219 & 0.9 & -1.3 & 0.100 & 5.0 & 0.112 & 5.2 \\
\hline
\end{tabular}

conclusion that feedback enabled by smart meters motivated in the consumption group 0-399 kWh per month to consume less electricity those customers who recognize the possibility to change behavior.

As shown in Table 2, there is a statistically significant difference between the means of consumption reduction in the consumption range above $400 \mathrm{kWh}$ per month in the target group. Respondents who did not want to receive additional information that would compare their usage with other relevant households' demonstrated reduction of $20.8 \%$, whereas consumers with interest to receive such information reduced consumption by $11.8 \%$. At the same time the subgroup who did not want this information answered more positively on questions about their current energy saving behavior. In comparison with the group who wanted additional information they stated more often that they are switching off unnecessary lighting, standby appliances, etc. It could be explained assuming that answering positively by respondents was related more to actual or desired behavior that together with feedback induced motivation results into energy saving actions. The same phenomenon was identified in the control group, however, no link with energy savings behavior was identified there. Therefore, more analysis to explain the findings is needed.

\section{CONCLUSIONS}

The review of literature suggests that the norm for savings from feedback is in a range from $5-15 \%$ and depends on a number of factors such as feedback type, the distribution of household consumption, weather conditions, local energy usage habits and appliances' stock, feedback content and its relevance within a particular market. Therefore, it is important to analyze feedback effects in a local context.

The findings from our study have shown that smart meter roll-out and provision of appropriate feedback information can provide significant energy savings for household customers. In comparison with the control group the average consumption of the target group fell by $19 \%$ year by year. At the same time there was $2 \%$ reduction for consumers with average monthly consumption between 250 and $399 \mathrm{kWh}$ per month but slightly above $20 \%$ consumption decrease in the range above $1500 \mathrm{kWh} /$ month. These electricity savings in percentage terms are significantly over the range that is reported by other pilot studies that describe savings in the range from 5 to $15 \%$ depending on feed-back type; however, it can be partially due to the fact that the study comprised a large share of high consumers.

Additionally, there was identified that feedback enabled by smart meters motivated in the 
consumption group 0-399 kWh per month to consume less electricity those customers who recognize the possibility to change their energy consumption behavior. Furthermore, it was identified that customer willingness to receive additional information does not necessarily correspond with later actions to reduce consumption. It could be related more to actual or desired behavior that together with feedback induced motivation results into energy saving actions.

Received 2 April 2014 Accepted 25 June 2014

\section{References}

1. Gans W., Alberini A., Longo A. Smart meter devices and the effect of feedback on residential electricity consumption: Evidence from a natural experiment in Northern Ireland. Energy Economics. 2013. Vol. 36. P. 729-743.

2. Sarah D. The Effectiveness of Feedback on Energy Consumption: a Review for DEFRA of the Literature on Metering, Billing and Direct Displays. Environmental Change Institute, University of Oxford, 2006.

3. Ehrhardt-Martinez K., Donnelly K. A., Laitner J. P. Advanced Metering Initiatives and Residential Feedback Programs: A Meta-Review for Household Electricity-Saving Opportunities. Report No. E105. American Council for an Energy-Efficient Economy, Washington, D. C., 2010.

4. VaasaEET. 2011. The Potential of Smart Meter Enabled Programs to Increase Energy and Systems Efficiency: A Mass Pilot Comparison - Empower Demand. Report for European Smart Metering Industry Group.

5. Lima C., Navas J. Smart metering and systems to support a conscious use of water and electricity. Energy. 2012. Vol. 45. P. 528-540.

6. Anda M., Temmen J. Smart metering for residential energy efficiency: The use of community based social marketing for behavioural change and smart grid introduction. Renewable Energy. 2014. Vol. 67. P. 119-127.

7. Ivanov C., Getachew L., Fenrick S., Vittetoe B. Enabling technologies and energy savings: The case of EnergyWise Smart Meter Pilot of Con- nexus Energy. Utilities Policy. 2013. Vol. 26. P. 76-84.

8. Oltra H., Boso A., Espluga J., Prades A. A qualitative study of users' engagement with real-time feedback from in-house energy consumption displays. Energy Policy. 2013. Vol. 61. P. 788792.

9. Schleich J., Klobasa M., Gölz S., Brunner M. Effects of feedback on residential electricity demand - Findings from a field trial in Austria. Energy Policy. 2013. Vol. 61. P. 1097-1106.

10. Darby S. J. Metering: EU policy and implications for fuel poor households. Energy Policy. 2012. Vol. 49. P. 98-106.

11. Hoaglin D. C., Iglewiez B. Fine tuning some resistant rules for outlier labeling. Journal of American Statistical Association. 1987. Vol. 82. P. 1147-1149.

12. Hargreaves T., Nye M., Burgess J. Keeping energy visible? Exploring how householders interact with feedback from smart energy monitors in the longer term. Energy Policy. 2013. Vol. 52. P. 126-134.

\section{Uldis Bariss, Ilze Laicane, Dagnija Blumberga}

\section{VEIKSNIŲ, TURINČIŲ İTAKOS ENERGIJOS VARTOJIMO EFEKTYVUMUI BANDOMAJAME SMART METERING („IŠMANIEJI SKAITIKLIAI“) PROJEKTE, ANALIZĖ}

\section{Santrauka}

Straipsnyje analizuojama 1000 namų ūkių, kuriems buvo pateikti išmanieji skaitikliai ir gautas elektros energijos vartojimo grižtamasis ryšys, studijos Latvijoje rezultatai. Paaiškejjo, kad išmaniųjų skaitikliụ naudojimas ir gaunamas grịžtamasis ryšys namų ūkiuose leidžia akivaizdžiai sumažinti energijos sąnaudas. Palyginus su kontroline grupe, vidutinis energijos suvartojimas tikslinèje grupejje sumažèjo $19 \%$. Be to, buvo nustatyta vartotojų grupé, per ménesi suvartojanti 0-399 kWh elektros energijos. Juos išmanieji skaitikliai labiau motyvavo mažinti elektros energijos vartojimą keičiant ịpročius. Taip pat nustatyta, kad vartotoju noras papildomai gauti informacijos nebūtinai sutampa su energijos vartojimo veiksmais siekiant sumažinti sąnaudas. Tai gali būti 
sietina su faktiniu ar siektinu elgesiu, kuris kartu su grižztamuoju ryšiu paveikia energijos tausojimo motyvacijos rezultatus.

Raktažodžiai: elektros energijos suvartojimas, išmanieji skaitikliai, namų ūkiai, grį̌tamasis ryšys

Улдис Барис, Ильзе Лайцане, Дагния Блумберга

\section{АНАЛИЗ ФАКТОРОВ, ВЛИЯЮЩИХ НА \\ ЭНЕРГОЭФФЕКТИВНОСТЬ В SMАRT \\ METERING („ИНТЕЛЛЕКТУАЛЬНЫЕ СЧЕТЧИКИ“) ПИЛОТНОМ ПРОЕКТЕ}

Резюме

Данная статья посвящена результатам обработки данных потребления электроэнергии для пилотного проекта, в котором принимали участие 1000 латвийских домашних хозяйств. Пользователи электроэнергии в этих хозяйствах делятся на две основные группы: потребители с интеллектуальными счетчиками и без них. Результаты пилотного проекта показывают снижение потребления электроэнергии на 19 \% для 500 клиентов в системах с интеллектуальным учетом электроэнергии. Анализ показывает, что значительное снижение констатировано для небольшой группы с потреблением электроэнергии от 0 до 390 кВт ч в месяц. Тем не менее, энергопотребление снизилось и для больших потребителей электроэнергии. Было также установлено, что желание сэкономить энергию не связано с дополнительной информацией, полученной благодаря установке умной системы учёта у потребителя. Это лишь мотивирует потребителя принять участие в энергосберегающих мероприятиях.

Ключевые слова: потребление электроэнергии, интеллектуальные счетчики, домашние хозяйства, обратная связь 
Appendix A. Survey of households' appliances and attitude towards their relative necessity

\begin{tabular}{|c|c|c|c|c|c|}
\hline \multirow[t]{2}{*}{ Appliance } & \multirow{2}{*}{$\begin{array}{c}\text { Power } \\
\text { W }\end{array}$} & \multirow{2}{*}{$\begin{array}{c}\text { Number } \\
\text { per HH }\end{array}$} & \multicolumn{2}{|c|}{ Relative necessity } & \multirow[b]{2}{*}{$C * * *$} \\
\hline & & & $A^{*}$ & B** & \\
\hline Fridge & 900 & 1.293 & $98.2 \%$ & $1.6 \%$ & $0.2 \%$ \\
\hline Separate freezer & 500 & 0.376 & $88.0 \%$ & $5.7 \%$ & $6.3 \%$ \\
\hline Electric hob & 6500 & 0.642 & $92.7 \%$ & $4.8 \%$ & $2.6 \%$ \\
\hline Electric oven & 2500 & 0.772 & $69.1 \%$ & $21.7 \%$ & $9.2 \%$ \\
\hline Electric hob with oven together & 7300 & 0.182 & $89.2 \%$ & $8.2 \%$ & $2.5 \%$ \\
\hline Cooker hood & 300 & 0.928 & $83.4 \%$ & $9.5 \%$ & $7.1 \%$ \\
\hline Dishwasher & 2200 & 0.621 & $64.7 \%$ & $17.6 \%$ & $17.8 \%$ \\
\hline Kettle & 2200 & 1.052 & $85.8 \%$ & $7.3 \%$ & $6.9 \%$ \\
\hline Coffee maker & 550 & 0.392 & $61.5 \%$ & $16.0 \%$ & $22.4 \%$ \\
\hline Toaster & 800 & 0.721 & $37.0 \%$ & $27.4 \%$ & $35.6 \%$ \\
\hline Microwave oven & 1000 & 0.672 & $54.0 \%$ & $21.3 \%$ & $24.8 \%$ \\
\hline Fryer & 2000 & 0.077 & $21.9 \%$ & $16.4 \%$ & $61.6 \%$ \\
\hline Electric grill & 1800 & 0.068 & $29.0 \%$ & $14.5 \%$ & $56.5 \%$ \\
\hline Electric steam boiler & 1800 & 0.084 & $38.0 \%$ & $19.0 \%$ & $43.0 \%$ \\
\hline Washing machine with a tumble dryer & 2300 & 0.188 & $94.6 \%$ & $4.8 \%$ & $0.6 \%$ \\
\hline Separate washing machine & 2200 & 0.882 & $97.9 \%$ & $1.8 \%$ & $0.3 \%$ \\
\hline Separate tumble dryer & 2300 & 0.130 & $80.0 \%$ & $12.5 \%$ & $7.5 \%$ \\
\hline Towel dryer & 40 & 0.233 & $61.1 \%$ & $16.7 \%$ & $22.2 \%$ \\
\hline Electric sauna or electric bath & 1600 & 0.142 & $28.6 \%$ & $31.0 \%$ & $40.5 \%$ \\
\hline Portable computer & 40 & 1.283 & $88.8 \%$ & $7.6 \%$ & $3.6 \%$ \\
\hline Desktop computers & 115 & 0.742 & $80.1 \%$ & $13.5 \%$ & $6.4 \%$ \\
\hline Tablet PC & 10 & 0.338 & $74.2 \%$ & $14.0 \%$ & $11.7 \%$ \\
\hline Analogue TV with tube & 195 & 0.496 & $72.5 \%$ & $16.0 \%$ & $11.5 \%$ \\
\hline Plasma TV & 220 & 0.406 & $79.3 \%$ & $16.0 \%$ & $4.7 \%$ \\
\hline LCDTV & 150 & 0.606 & $76.2 \%$ & $15.7 \%$ & $8.1 \%$ \\
\hline LEDTV & 62 & 0.218 & $77.5 \%$ & $15.6 \%$ & $6.9 \%$ \\
\hline DVD player & 15 & 0.656 & $25.8 \%$ & $27.0 \%$ & $47.2 \%$ \\
\hline Home cinema & 300 & 0.283 & $37.5 \%$ & $26.3 \%$ & $36.3 \%$ \\
\hline Speakers, music center & 15 & 0.563 & $45.1 \%$ & $26.4 \%$ & $28.5 \%$ \\
\hline Carpet sweeper & 1800 & 1.127 & $85.7 \%$ & $9.3 \%$ & $5.0 \%$ \\
\hline Hair straightener & 1000 & 1.257 & $82.6 \%$ & $11.6 \%$ & $5.7 \%$ \\
\hline Flat iron & 2000 & 1.095 & $82.7 \%$ & $14.6 \%$ & $2.7 \%$ \\
\hline Shoe dryer rack & 80 & 0.031 & $42.9 \%$ & $32.1 \%$ & $25.0 \%$ \\
\hline Bulk water heater (boiler) & 2000 & 0.567 & $92.4 \%$ & $3.6 \%$ & $4.0 \%$ \\
\hline Instantaneous water heater (boiler) & 12000 & 0.078 & $87.1 \%$ & $1.4 \%$ & $11.4 \%$ \\
\hline Humidifier & 200 & 0.107 & $52.9 \%$ & $17.2 \%$ & $29.9 \%$ \\
\hline Ventilation equipment & 16 & 0.472 & $73.8 \%$ & $13.1 \%$ & $13.1 \%$ \\
\hline Air conditioning & 2300 & 0.214 & $45.6 \%$ & $22.4 \%$ & $32.0 \%$ \\
\hline $\begin{array}{c}\text { Electric heaters (oil radiators, } \\
\text { thermal ventilators, etc.) }\end{array}$ & 1500 & 0.520 & $41.4 \%$ & $17.6 \%$ & $41.0 \%$ \\
\hline Water filtration system & 25 & 0.260 & $94.6 \%$ & $2.2 \%$ & $3.1 \%$ \\
\hline Electric gates & 350 & 0.419 & $85.2 \%$ & $4.7 \%$ & $10.1 \%$ \\
\hline Other & 1051 & & $64.8 \%$ & $18.7 \%$ & $16.6 \%$ \\
\hline Total & & & $79.8 \%$ & $10.7 \%$ & $9.5 \%$ \\
\hline
\end{tabular}

In the survey 944 respondents answered the question to evaluate whether they can use the appliance more seldom or its usage is essential.

The following answer options were given:

${ }^{*} A$ - the appliance is essential.

* B - the appliance is essential but it could be used less.

${ }^{*} \mathrm{C}$ - the appliance is not essential but it is used for comfort and can be used significantly less. 